\title{
L'Ami arménien
}

\author{
Andreï Makine, 2021 \\ Publisher: Grasset \\ Pages: 214 \\ Language: French
}

\section{Louis Marmion, University College London}

L'Ami arménien is Andreï Makine's eighteenth novel, or twenty-second if counting those written under his nom de plume Gabriel Osmonde. Makine rose to fame in 1995 with his fourth, Dreams of My Russian Summers, which won him France's most coveted literary honours: the Goncourt, Goncourt des Lycéens and Médicis prizes. Prior to that, the Soviet-born author lived in obscurity, having sought asylum in France in the late 1980s. In recognition of his contributions to the French language, he was elected to the Académie française in 2016. This review of L'Ami arménien pays particular attention to the philosophical undercurrent of the novel, while drawing comparisons with Makine's previous works.

Despite his literary fame, biographical information about Makine's life in the USSR is scarce. It is therefore significant that Grasset, the author's publisher, promoted his latest bildungsroman as 'reveal[ing] a crucial episode in the life of Andreï Makine'. This admission of authorial rapprochement appears to be an explicit attempt at marketing Makine's 'private legend'. The objective here was clearly to appeal to a demographic of readers intent on seeking personal information about the reticent novelist.

Set in Krasnoyarsk in the 1970s, we follow the orphaned narrator (a thinly-veiled thirteen-yearold Makine) and his account of Vardan, a sickly classmate with whom he forms a life-defining bond. Vardan lives in 'the Devil's End': a neglected neighbourhood on the city's periphery, where members of the Armenian diaspora have set up camp while they await the sentencing of their loved ones in a nearby prison. In this 'Kingdom of Armenia' Vardan introduces the narrator to a new way of life. What Makine reveals here is the genesis of the philosophical outlook, which has served as an important leitmotif in his past works. It is also a hint at the likely source of inspiration for another visionary character of his, Pashka, from Dreams. In fact, L'ami appears like a true companion piece to Dreams, also a bildungsroman, with its shared narrative structures, autobiographical import and metanarratives on the constructs of national and cultural identity. That said, L'ami is not as dense, perhaps due to the economy of words that Makine has developed in the twenty-sixyears separating the two publications. The 'master of the ellipsis' leaves nothing extraneous, propelling the narrative with the efficiency and thematic consistency that characterise some of his best works.

It is therefore to the novel's detriment that Makine reverts to his worst impulses in the closing chapter, where the narrative takes the protagonist to present-day Krasnoyarsk. In line with his 
'increasingly preachy' novels of the past two decades, Makine produces one of his trademark diatribes, lambasting anyone that stands in the way of his ascetic quest for the 'essential truth' in life. The usual culprits-glutinous consumers and shallow materialists, hypocritical humanitarians, exponents and practitioners of globalisation, modern art and the liberal elite that laps it up-are all present. This tirade seems futile as Makine explored these topics at length in the 2019's Au-delà des frontières (Beyond Borders), which polarised critics with its reactionary discourse. What redeems this chapter is a brief but interesting commentary on the tensions between exile, identity and the concept of 'global citizenship'. The narrator predicts that Vardan's family of Armenian exiles would have found no place in today's globalised world, in which exoticism is a prized commodity and cultural diversity tends to be idealised. He reasons that their ambivalence-foreign yet unabashedly un-exotic, culturally rich yet materially destitute-problematises this appeal.

After his divisive last publication, L'ami feels like a welcome return to form for the classical novelist. Avid readers and scholars of Makine alike would benefit from revisiting Dreams with the tensions introduced by L'ami in mind. For non-francophone readers, the most recent English translation of Makine's prose is The Archipelago of Another Life (2016). 